\title{
Long-term declines of wader populations at the Tagus estuary, Portugal: a response to global or local factors?
}

\author{
TERESA CATRY, JOSÉ A. ALVES, JOANA ANDRADE, HELDER COSTA, \\ MARIA P. DIAS, PEDRO FERNANDES, ANA LEAL, PEDRO M. \\ LOURENÇO, RICARDO C. MARTINS, FILIPE MONIZ, SARA PARDAL, \\ AFONSO ROCHA, CARLOS D. SANTOS, VITOR ENCARNAÇÃO \\ and JOSÉ P. GRANADEIRO
}

\begin{abstract}
Summary
Migratory wader populations face global threats, mainly related to increasing rates of habitat loss and disturbance driven by human activities. To a large extent, the long-term survival of these populations requires the conservation of networks of sites along their migratory flyways. The Tagus estuary, Portugal, is among the most important wetlands for waders in the East Atlantic Flyway. Annual winter wader counts have been carried in this wetland since 1975 and a monthly roost-monitoring programme was implemented in 2007. Wintering populations of three out of the five most abundant species, Dunlin Calidris alpina, Grey Plover Pluvialis squatarola and Redshank Tringa totanus, showed significant population declines over the past three decades, which are most likely due to the loss and degradation of roost sites as a result of increasing human activity. The situation is unlikely to improve, as a high proportion of the wintering waders use roost sites that are situated in highly urbanised areas with no legal protection. The use of different roost sites by waders is highly variable both temporally and spatially, thus emphasizing the need for a network of good quality roost sites. Additionally, during migration, $60-80 \%$ of all the waders of the Tagus estuary concentrate at a single refuge, thus increasing the risk for wader populations during these periods.
\end{abstract}

\section{Sumário}

As populações de aves limícolas migradoras enfrentam ameaças globais, maioritariamente relacionadas com a crescente perda de habitat e perturbação humana. Para garantir a sobrevivência a longo-termo destas populações é imprescindível a conservação de uma rede de áreas húmidas ao longo das suas rotas migratórias. O estuário do Tejo, em Portugal, é uma das mais importantes áreas húmidas para aves limícolas na rota Migratória do Atlântico Este. Desde 1975, foram efectuadas contagens anuais de aves limícolas no inverno nesta zona húmida e, em 2007, foi implementado um programa de monitorização mensal dos refúgios de preia-mar. As populações invernantes de três das cinco espécies de limícolas mais abundantes no estuário, o Pilrito-de-peito-preto Calidris alpina, a Tarambola-cinzenta Pluvialis squatarola e o Perna-vermelha Tringa totanus, mostraram tendências significativas de decréscimo nas últimas três décadas, potencialmente devido à degradação e perda de refúgios como resultado da crescente actividade antropogénica. Esta situação poderá deteriorar-se, uma vez que uma grande proporção das aves limícolas invernantes utiliza refúgios em áreas densamente urbanizadas sem qualquer estatuto legal de 
protecção. A utilização dos diferentes refúgios do estuário do Tejo por aves limícolas tem uma grande variação espacial e temporal, o que reforça a importância da existência de uma rede de refúgios de elevada qualidade nesta área húmida. Durante a migração, 60 a $80 \%$ das aves limícolas concentram-se num único refúgio, ficando assim particularmente vulneráveis neste período.

\section{Introduction}

Wader populations are declining worldwide, representing a matter of international conservation concern (International Wader Study Group 2003). Habitat loss and disturbance, mainly as a result of increasing human activity, are among the main causes of these declines (Goss-Custard and Yates 1992; Davidson and Rothwell 1993). Estuaries traditionally hold large numbers of waders during the non-breeding season, acting both as wintering and stopover areas. Estuarine waders are particularly threatened by land reclamation and the consequent changes in natural habitats due to urbanisation, dyke construction and conversion of semi-natural habitats as saltpans into aquacultures (van de Kam et al. 2004). Similarly, pressure from recreational activities has markedly increased and is presently very high and widespread in many important areas (Davidson and Rothwell 1993, van de Kam et al. 2004). In addition, the negative impacts of climate change on shorebirds, particularly of sea level rise, are just starting to be modelled and quantified, but will most probably cause significant losses of both feeding and roosting areas (Watkinson et al. 2004, Galbraith et al. 2005, Durell et al. 2006). Although the numbers and distribution of estuarine waders is mainly determined by the availability of suitable foraging areas, high tide roosts are a crucial and often limiting habitat. In fact, loss of roosting sites may substantially increase the energetic costs of waders (due to increased flight time) and decrease their probability of survival (Durell et al. 2005). In addition, roost availability is known to limit access to feeding areas (Dias et al. 2006, Rogers et al. 2006, van Gils et al. 2006), given the need to minimise the energy costs of flying between roosting and feeding sites (Rogers 2003). Previous studies have showed that good quality feeding sites (offering high intake rates) are only used frequently if roosting occurs close by (Dias et al. 2006, van Gils et al. 2006), which might constrain the carrying capacity of estuaries.

The Tagus estuary, Portugal, is one of the largest estuarine wetlands in Europe and the second most important wetland for waders in Iberia (Delany et al. 2009), holding regularly c.50,000 waders during the winter (Moreira 1997). It has a strategic geographical position within the East Atlantic Flyway holding important, but mostly unquantified, populations of migratory waders during both the spring and autumn migration periods. This wetland has been classified as internationally important under the Ramsar Convention for supporting more than $1 \%$ of the relevant wintering populations of Avocet Recurvirostra avosetta, Black-tailed Godwit Limosa limosa, Grey Plover Pluvialis squatarola, Dunlin Calidris alpina, Ringed Plover Charadrius hiaticula, Bar-tailed Godwit Limosa lapponica, and of the breeding population of Black-winged Stilt Himantopus himantopus (Delany et al. 2009). Moreover, in some years it holds c. $40 \%$ of the western European population of Black-tailed Godwit during the spring migration period (Lourenço et al. 2010). Despite its international importance, long-term trends in wader populations at this wetland are virtually unknown. Determination of such trends is particularly relevant given the importance of the site and recent reports of loss or degradation of several roosting sites in the area (Dias et al. 2006).

In the present study we (I) assess population trends of the most abundant wintering waders at the Tagus estuary during the last three decades, (2) describe seasonal variations in wader abundance and (3) evaluate the relative importance of distinct roosts throughout the annual cycle for most wader species. In addition, we briefly examine the effectiveness of the existing protected areas and their suitability for the conservation of the whole assemblage of waders in this wetland. 


\section{Methods}

\section{Study area}

The intertidal area of the Tagus estuary, Portugal $\left(38^{\circ} 45^{\prime} \mathrm{N}, 09^{\circ} 50^{\prime} \mathrm{W}\right)$, covers about $97 \mathrm{~km}^{2}$ and is mostly composed of mud flats with smaller areas dominated by sandy sediments. Saltmarshes, saltpans (mainly abandoned or transformed into aquacultures) and, to a lesser extent, agricultural fields (such as rice fields; Masero et al. 2011), are also used by waders, mainly as high-tide roosts (see Table 1 for a description of roost sites). The northern areas of the estuary were designated as nature reserve in 1976 and a larger area, including intertidal areas and surrounding land, was designated in 1988 as a Special Protection Area (SPA), under European Union legislation (Figure 1).

\section{Bird counts at the Tagus estuary and elsewhere}

Annual wader counts were carried out in January between 1975 and 2006 at the main high-tide roosts of the Tagus estuary, including the northern saltmarshes (Rufino 1979, Rufino 1982, Costa and Rufino 1994, Costa and Rufino 1997, ICNB unpubl. data). In this period, all roost sites were counted by two observers, usually in a single day, sometimes in two consecutive days, and assessed by land, with the exception of the northern saltmarshes, which were counted by boat. From January 2007 onwards, we set up a more intensive monitoring scheme of the 13 most important roosts of the Tagus estuary (excluding the northern saltmarsh area; Figure 1 ). In this new scheme, bird counts were carried out monthly, during the spring tides of the second fortnight of each month. Counts were carried out within a 5-day period (maximum) and took place exclusively during spring tides with amplitudes higher than $3.3 \mathrm{~m}$, in order to ensure that all birds present in the estuarine flats had moved to the high tide roosts (Rosa et al. 2006, pers.obs.). Depending on the size of the roost and on the distribution of the roosting birds (highly gathered

Table 1 . Characteristics and legal protection status of high-tide roosts at the Tagus estuary. RNET $=$ Tagus Estuary Nature Reserve, SPA = Special Protection Area for Birds; na = not applicable.

\begin{tabular}{|c|c|c|c|c|}
\hline Roost & Habitat type & Human exploitation & $\begin{array}{l}\text { Water level } \\
\text { control }\end{array}$ & $\begin{array}{l}\text { Legal } \\
\text { protection }\end{array}$ \\
\hline Alverca (I) & saltpans & $\begin{array}{l}\text { partly converted into a } \\
\text { sewage treatment station }\end{array}$ & no & none \\
\hline Vasa Sacos (2) & saltpans & grass shrimp aquaculture & partly & RNET \& SPA \\
\hline Vale de Frades (3) & saltpans & none & no & RNET \& SPA \\
\hline Bela Vista (4) & saltpans & $\begin{array}{l}\text { partly converted in grass } \\
\text { shrimp aquaculture }\end{array}$ & no & SPA \\
\hline Atalaia (5) & saltpans & $\begin{array}{l}\text { partly converted in grass } \\
\text { shrimp aquaculture }\end{array}$ & no & SPA \\
\hline Tarouca (6) & saltpans & $\begin{array}{l}\text { partly converted in grass } \\
\text { shrimp aquaculture }\end{array}$ & no & SPA \\
\hline Samouco $(7)$ & saltpans & managed for birds & yes & SPA \\
\hline Sarilhos (8) & $\begin{array}{l}\text { saltpans and } \\
\text { saltmarsh }\end{array}$ & $\begin{array}{l}\text { project for fish aquaculture } \\
\text { in saltpans }\end{array}$ & no & SPA \\
\hline Moita (9) & saltpans & none & no & none \\
\hline Alhos Vedros (10) & $\begin{array}{l}\text { saltmarsh and } \\
\text { saltpans }\end{array}$ & $\begin{array}{l}\text { saltpans are starting to be } \\
\text { converted in grass shrimp } \\
\text { aquaculture }\end{array}$ & no & none \\
\hline Coina (II) & saltmarsh & none & na & none \\
\hline Seixal (12) & saltmarsh & regular bait-digging activity & na & none \\
\hline Corroios (13) & saltmarsh & none & na & none \\
\hline
\end{tabular}




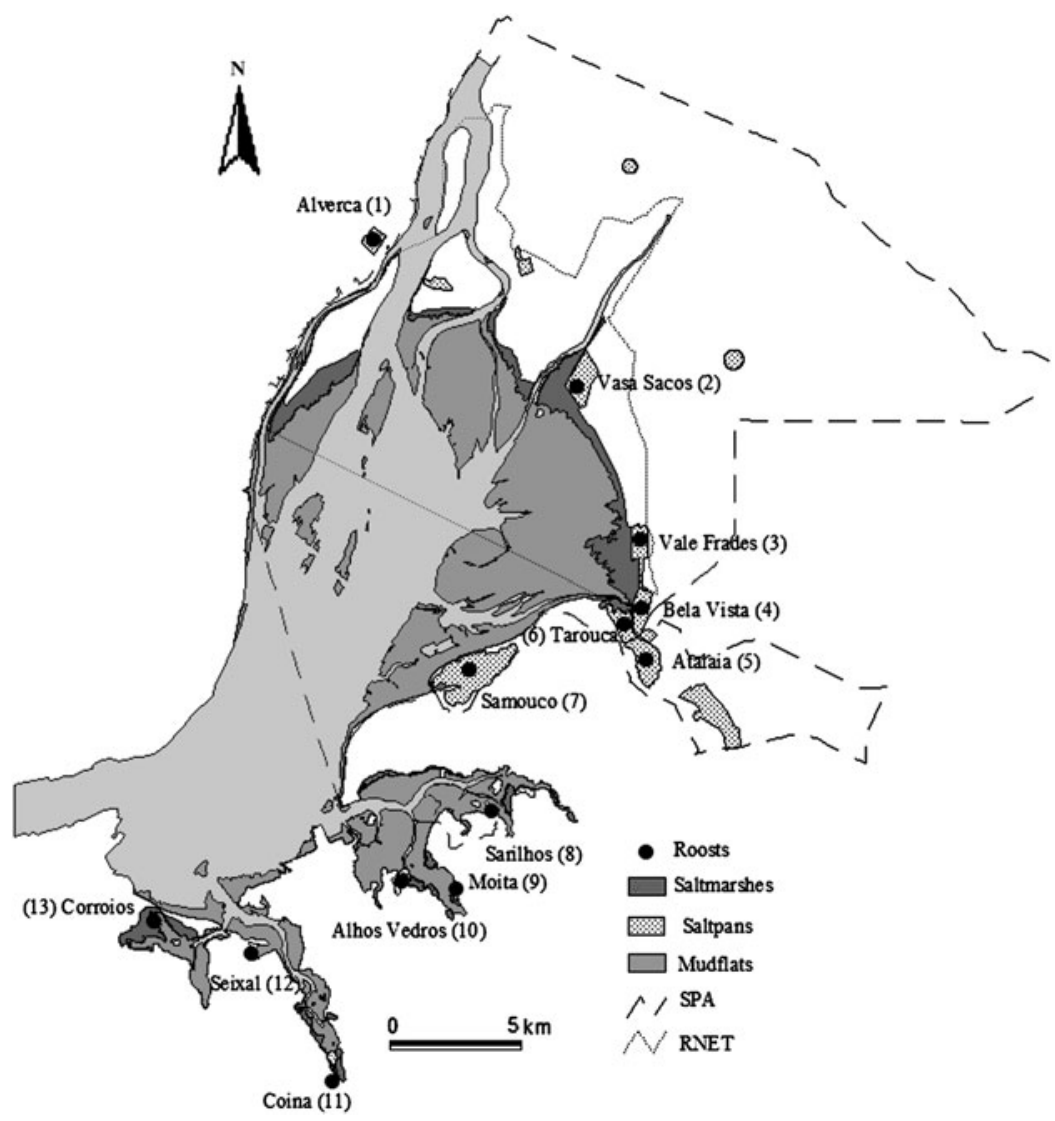

Figure 1. Map of the study area with the location of monitored roosts and the boundaries of the Special Protection Area for Birds (SPA) and the Tagus Estuary Nature Reserve (RNET).

or dispersed), one or two observers counted the birds as they entered the refuge or when they were already settled. Non-simultaneous counts could lead to potential errors if birds move between roosts in consecutive days. However, this could hardly have biased the main results and conclusions about seasonal variations in wader abundance, given the overall annual consistency of the phenological patterns.

Long-term trends (1975-2010) of five common wader species at three other important national wetlands (Ria de Aveiro, Sado estuary and Ria Formosa; Rufino 1979, Rufino 1982, Costa and Rufino 1994, Costa and Rufino 1997, ICNB unpubl. data) are also presented to assess the relative contribution of local and global factors in explaining potential variations in numbers of waders at the Tagus estuary.

\section{Data analysis}

We used the software package TrendSpotter to assess significant long-term trends in five wader species at Tagus estuary, Ria de Aveiro, Sado estuary and Ria Formosa. Missing values in our initial dataset were imputed using the program Trends and Indices for Monitoring Data (TRIM; Pannekoek and van Strien 2001). TrendSpotter uses a smoothing method from the class of structural time-series analysis in combination with the Kalman filter (Visser 2004, Soldaat et al. 
2007). This software estimates smoothed population numbers and their standard deviations, and allows the estimation of confidence intervals based on the deviations of time point values from the smoothed line. It is then possible to test the difference between the smoothed population number of the last year of a time series against each of the preceding years (total change rate - TCR), taking into account serial correlation. Mean yearly change rate (YCR) estimates, i.e. the TCR expressed as a mean change rate per year, and confidence intervals, were used to classify the trends per year in six categories: "strong increase", "moderate increase", "stable", "moderate decline", "steep decline" and "uncertain" (see Soldaat et al. 2007 for further details on TCR and YCR calculations and trend classification). All data counts were ln-transformed prior to the analysis. A "population alert" system has been implemented in the UK by the British Trust for Ornithology (BTO), in order to identify strong $(>50 \%)$ and moderate declines $(25-49 \%)$ in national and regional bird populations over different time series (Atkinson et al. 2006). In this study, we use TrendSpotter to calculate alerts through the conversion of the TCR values: an upper TCR confidence interval lower than 0.75 or lower than 0.50 represents an alert threshold of $25 \%$ and of $50 \%$, respectively (Soldaat et al. 2007).

For some of the analyses, monthly count data collected from 2007 onwards at the Tagus estuary were pooled seasonally: autumn migration (September and October), winter (November, December, January and February), spring migration (March, April and May) and summer (June, July and August). The Shannon diversity index $(\mathrm{H})$ was used to compare the distribution of waders in the roosts of the Tagus estuary between winter and migratory periods, in order to identify differences in the roosting behaviour of wintering $v s$. migratory birds, namely if birds are more gregarious during a particular season, which might have important conservation implications. Given that the number of roosts was similar in both periods, the diversity index reflects the evenness of birds in the different monitored roosts. Differences in $\mathrm{H}$ between winter and the migratory periods (spring and autumn seasons pooled) were tested against 10oo bootstrap replicates, following Hammer et al. (2001).

Overall, results are presented as mean \pm standard deviation (SD). Computations were carried out using the R software (R Development Core Team 2007).

\section{Results}

\section{Long-term trends in wintering wader populations}

Three of the five most abundant wintering waders at the Tagus estuary have significantly declined over the past 30 years, namely Dunlin, Grey Plover and Redshank (Table 2, Figure 2). The steepest decline over the whole time series was recorded for Dunlin, whose numbers frequently exceeded 20,000 individuals during the 1970s, 1980s and 1990s, but barely reached 10,000 birds during the last decade (Figure 2). The Dunlin population trend triggers a strong alert for a decline $(>50 \%)$ over the last 30 years, and moderate alerts $(25 \%-49 \%$ decline) over the last 20 and 10 years. Population changes undergone by wintering Grey Plovers generate a strong alert for a decline at the Tagus estuary over the last 20 years, and moderate declines during the whole time series and over the last 1o years. Moderate alerts are produced for declines in Redshank population across the last 30 and 20 years (Table 3). Numbers of Black-tailed Godwit and Avocet at the Tagus estuary showed high inter-annual variation but, with the exception of a moderate decline in the Avocet population until the late 1980s (insufficient to trigger an alert), the overall trends look stable (Table 2; Figure 2).

At the other three wetlands, long-term declines were exclusively recorded at Ria de Aveiro, for Black-tailed Godwit, Avocet and Redshank (Table 2, Figure 3).

\section{Seasonal variations in wader populations and high-tide roost use}

Between 2007 and 2009, an average of $16,817 \pm 7,596(n=34)$ waders were counted each month in the main roosts of the Tagus estuary. The minimum number of birds was consistently recorded 
Table 2. Population trends of Dunlin, Grey Plover, Black-tailed Godwit, Avocet and Redshank at the study area (Tagus estuary) and at three other important Portuguese wetlands (Ria Aveiro, Sado estuary and Ria Formosa). Trend legend: $\uparrow \uparrow$ strong increase, $\uparrow$ moderate increase, $\longleftrightarrow$ stable, $\downarrow$ moderate decline, $\downarrow \downarrow$ steep decline, ? uncertain.

\begin{tabular}{|c|c|c|c|c|c|c|c|c|}
\hline & \multicolumn{2}{|c|}{ Tejo estuary } & \multicolumn{2}{|l|}{ Ria Aveiro } & \multicolumn{2}{|c|}{ Sado estuary } & \multicolumn{2}{|l|}{ Ria Formosa } \\
\hline & Period & Trend & Period & Trend & Period & Trend & Period & Trend \\
\hline Dunlin & $1975-2006$ & $\downarrow$ & $1975-2010$ & $\uparrow$ & $1975-2010$ & $\uparrow$ & $\begin{array}{l}1975-1993 \\
1994-1999 \\
2000-2010\end{array}$ & $\begin{array}{l}\longleftrightarrow \\
?\end{array}$ \\
\hline Grey Plover & $\begin{array}{l}1975-1985 \\
1986-1996 \\
1997-2006\end{array}$ & $\begin{array}{l}\downarrow \\
\downarrow \downarrow \\
\downarrow\end{array}$ & $\begin{array}{l}1975-1979 \\
1980-2010\end{array}$ & $\stackrel{\uparrow}{\longleftrightarrow}$ & $\begin{array}{l}1975-1987 \\
1988-2000 \\
2001-2010\end{array}$ & $\stackrel{\uparrow}{\longleftrightarrow}$ & $\begin{array}{l}1975-1979 \\
1980-1993 \\
1994-2010\end{array}$ & $\stackrel{\uparrow}{\longleftrightarrow}$ \\
\hline Black-tailed Godwit & $1975-2006$ & $\longleftrightarrow$ & $1975-2010$ & $\downarrow$ & $1975-2010$ & $\uparrow \uparrow$ & $\begin{array}{l}1975-1987 \\
1988-1990 \\
1991-2000 \\
2001-2010\end{array}$ & $\begin{array}{l}\longleftrightarrow \\
? \\
\downarrow\end{array}$ \\
\hline Avocet & $\begin{array}{l}1975-1987 \\
1988-2006\end{array}$ & $\stackrel{\downarrow}{\longleftrightarrow}$ & $1975-2009$ & $\downarrow$ & $\begin{array}{l}1975-1982 \\
1983-2006 \\
2006-2010\end{array}$ & $\stackrel{\uparrow}{\longleftrightarrow}$ & $\begin{array}{l}1975-1983 \\
1984-2000 \\
2001-2010\end{array}$ & $\stackrel{\uparrow}{\longleftrightarrow}$ \\
\hline Redshank & $\begin{array}{l}1975-2001 \\
2001-2006\end{array}$ & $\stackrel{\downarrow}{\longleftrightarrow}$ & $1975-2010$ & $\downarrow$ & $1975^{-2010}$ & $\uparrow$ & $1975-2010$ & $\longleftrightarrow$ \\
\hline
\end{tabular}

in May-June, whereas the season with highest abundances showed considerable annual variation: 32,519 birds in April 2007, during spring migration; 26,992 birds in February 2008, during winter, and 21,674 birds in September 2009, during autumn migration (Figure 4). The peak abundance of most species coincided with the migration periods (Appendix $\mathrm{S}_{1}$ in online Supplementary Material).

The relative importance of each roost site varied seasonally and by species (Table 4, Appendix S2). Samouco saltpans (roost 7) harboured the largest numbers of waders all year round, especially during the migration periods, when $60-80 \%$ of all waders passing through the Tagus estuary used this area. Overall, birds were more evenly distributed in the roosts in winter than during the migration periods (Shannon diversity index $H=1.77$ and $H=1.26$, for winter and migration periods respectively, $P<$ o.001), when few birds used the roosts located in the southern part of the estuary (see also Table 4).

The percentage of birds roosting in areas outside the designated SPA exceeded $30 \%$ during winter for each of the five most abundant wader species (Table 5). These figures varied seasonally and with species; for example, during autumn, more than $50 \%$ of the Redshank population used refuges in areas that lack any status of legal protection (Table 5).

\section{Discussion}

\section{Long-term trends in wintering wader populations}

Count data from the last three decades have shown major declines in some of the most abundant wader species at the Tagus estuary, with strong and/or moderate alerts triggered for the declines of Dunlin, Grey Plover and Redshank. The apparent stability of the populations of Dunlins from the subspecies $C$ a. alpina (the most represented subspecies at the Tagus estuary) at a global level (Delany et al. 2009), is at variance with the trend in the Tagus estuary, providing strong evidence of a decline due to local factors. Changes in wader population size could also result from a shift in species' distribution. Climate change is inducing waders to winter closer to their breeding grounds, thus promoting declines in the populations at their southern distribution ranges 

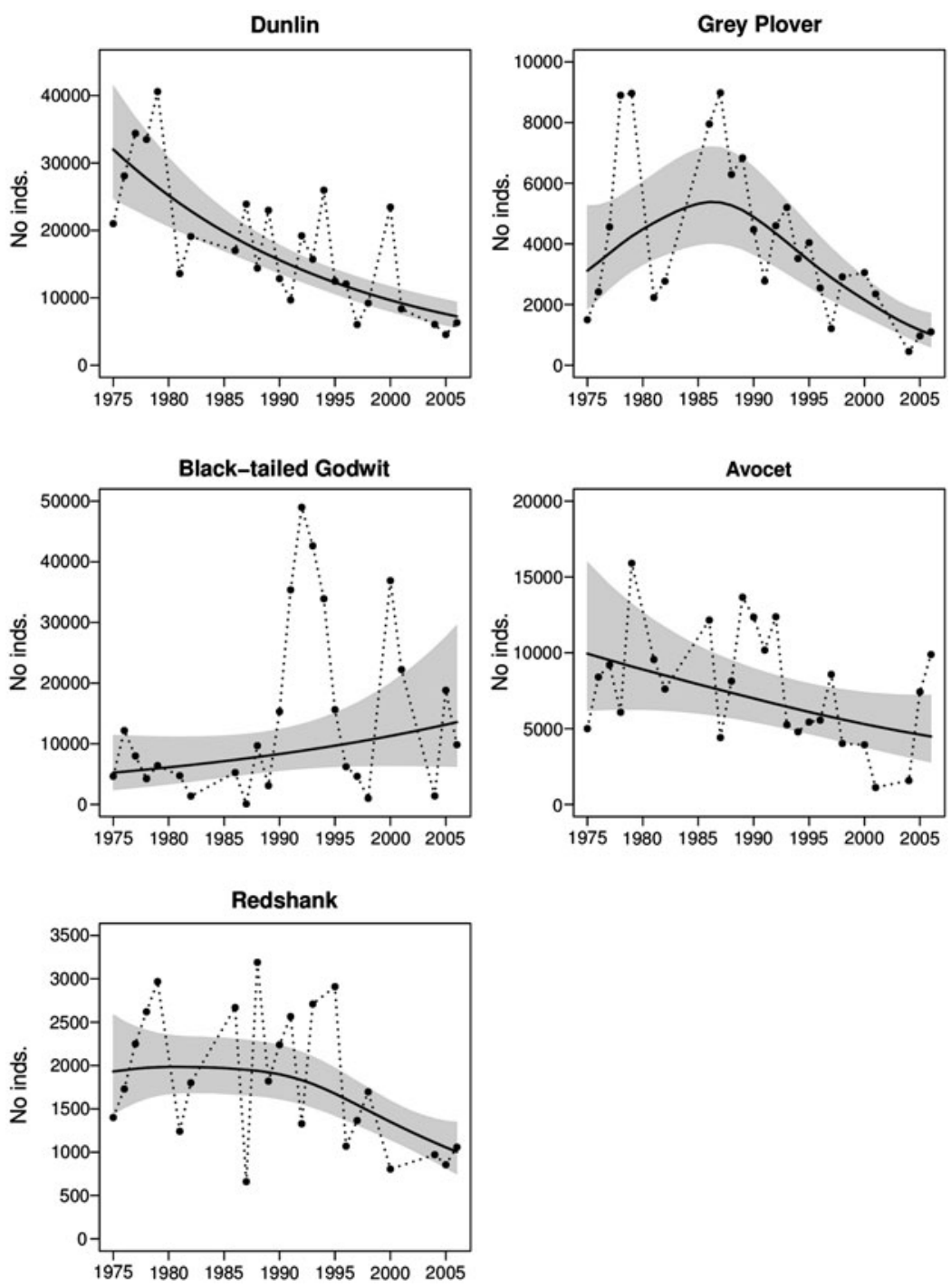

Figure 2. Abundance of the five most important wader species at the Tagus estuary between 1975 and 2006 (from January counts). Overall trends are represented by a solid line (smoothed population numbers estimated by TrendSpotter) and the grey shaded area represents $95 \%$ confidence intervals. Significant declines were recorded for Dunlin, Grey Plover and Redshank (see text).

(Rehfisch et al. 2004). However, Dunlins are not declining in any of the other major Portuguese wetlands, which also support the idea of a local decline. Conversely, the decrease of Grey Plovers in the Tagus estuary is in agreement with the global decrease of the eastern Atlantic population (Delany et al. 2009). Uncertainty in European trends of Redshanks (Delany et al. 2009) prevents a direct comparison with the decline recorded at the Tagus estuary. Nonetheless, it is likely that the local factor responsible for the decline of Dunlin populations might also affect other species with similar ecological requirements, such as Grey Plover and Redshank. 
Table 3. Population alerts triggered for Dunlin, Grey Plover, Black-tailed Godwit and Redshank at the Tagus estuary and Ria Aveiro during different time periods. No alerts were generated for Avocet or for any species at Sado estuary and Ria Formosa. Moderate and strong alerts correspond to $>25 \%$ and $>50 \%$ declines, respectively.

\begin{tabular}{|c|c|c|c|c|c|}
\hline & \multirow{2}{*}{$\frac{\text { Dunlin }}{\text { Tagus estuary }}$} & \multirow{2}{*}{$\frac{\text { Grey Plover }}{\text { Tagus estuary }}$} & \multirow{2}{*}{$\frac{\text { B.-tailed Godwit }}{\text { Ria Aveiro }}$} & \multicolumn{2}{|l|}{ Redshank } \\
\hline & & & & Tagus estuary & Ria Aveiro \\
\hline $\begin{array}{l}35 \text { years } \\
30 \text { years } \\
20 \text { years } \\
\text { 10 years }\end{array}$ & $\begin{array}{l}- \\
\text { strong alert } \\
\text { moderate alert } \\
\text { moderate alert }\end{array}$ & $\begin{array}{l}\text { - } \\
\text { moderate alert } \\
\text { strong alert } \\
\text { moderate alert }\end{array}$ & $\begin{array}{l}\text { moderate alert } \\
\text { moderate alert } \\
\text { moderate alert } \\
\text { no alert }\end{array}$ & $\begin{array}{l}\text { - } \\
\text { moderate alert } \\
\text { moderate alert } \\
\text { no alert }\end{array}$ & $\begin{array}{l}\text { moderate alert } \\
\text { moderate alert } \\
\text { moderate alert } \\
\text { no alert }\end{array}$ \\
\hline
\end{tabular}

\section{Seasonal variations in wader populations and in high-tide roost use}

Overall, the phenological patterns of most waders presented in this study coincide with those previously described for the Tagus estuary (Moreira 1995) and other Iberian wetlands (e.g. Lopes et al. 2005, Masero et al. 2000). However, our data clearly show the importance of the estuary as a stopover area, both during spring and autumn migration periods. Indeed, most species reach peak abundance during these periods and the total abundance of staging populations is certainly higher given that even peak counts are known to underestimate the total passage population due to the turnover rates of migrants (Schaub et al. 2001, Frederiksen et al. 2001, Gillings et al. 2009).

Waders regularly used c.1o roosts in the Tagus estuary and its importance varied seasonally. In fact, the roosts located in the southern part of the estuary held large numbers of birds during the winter, but apparently most of the birds were concentrated in the northern part of the estuary during migratory periods. This seasonal variation in the relative importance of the roost emphasises the need for a network of good quality roost sites around the entire intertidal area. This requirement is certainly applicable to medium to large-size estuaries worldwide, where the cost of commuting between roosting and foraging areas forms an important part of the bird's time and energetic budget (Mitchell et al. 1988, Rogers et al. 2006).

Samouco (roost 7) is currently the most important roost in the Tagus estuary, not only for harbouring several thousand waders all year round but mostly because those numbers correspond to $30-80 \%$ (depending on the year and season considered) of all the waders on this wetland. Roost quality and, consequently, roost selection, have been found to be related to distance to feeding areas, predation risk, human disturbance and thermoregulation costs (Dias et al. 2006, Rogers et al. 2006, Rosa et al. 2006, Peters and Otis 2007). Samouco is a very large saltpan complex, which has been partly managed for waterbirds since 2007. Levels of disturbance are comparatively low (given the restricted access to the area) and the low water level in the managed tanks provides feeding opportunities during the high-tide period, which might partly explain its relative importance.

\section{Roost loss and degradation as the likely cause of local wader declines}

In the Tagus estuary, several roosts have disappeared in the last decades, while others are presently threatened by human activities (Dias et al. 2006), and this is likely to be one of the most relevant causes of wader declines (see below). By contrast, there is no evidence of recent changes in the quality of intertidal areas that could explain such declines. In fact, the current implementation of a sewage treatment network on the Tagus estuary that could affect the quality of intertidal flats seems to have a low impact on the overall density and biomass of benthic prey, and consequently on the abundance of waders (Alves 2009). Conversely, a recent study has shown that the current harvesting levels of shellfishing are compatible with the preservation of intertidal flats as foraging areas for waders (Dias et al. 2008).

Several studies have linked wader population declines with disturbance or loss of high tide roosting sites (Mitchell et al. 1988, Pfister et al. 1992, Burton et al. 1996). At the Tagus estuary several pieces 

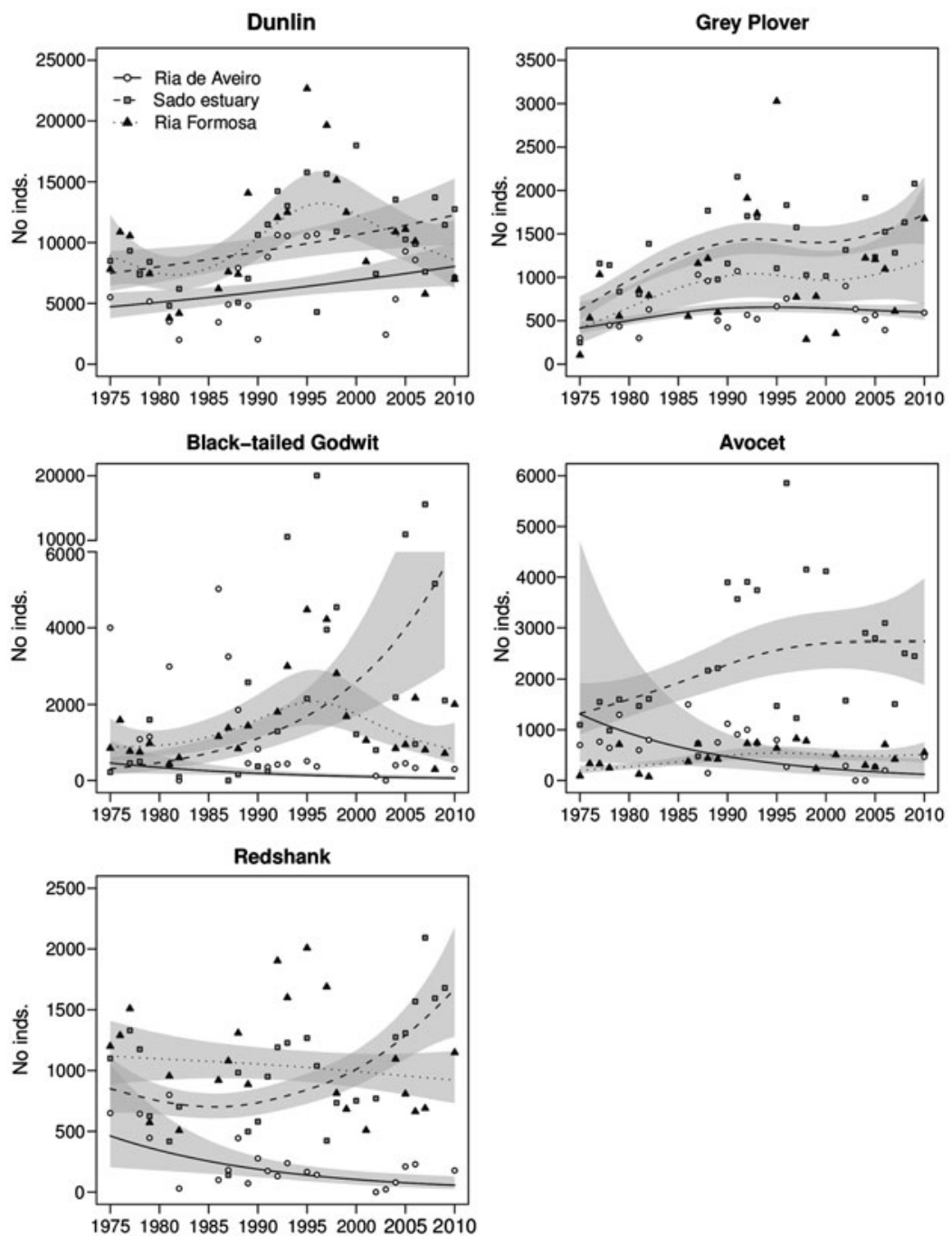

Figure 3. Abundance of the five most important wader species at three major Portuguese wetlands, Sado estuary, Ria Formosa and Ria de Aveiro, between 1975 and 2010 (from January counts). Overall trends are represented by a solid line (smoothed population numbers estimated by TrendSpotter) and the grey shaded area represents $95 \%$ confidence intervals. Significant declines over the entire time-series were recorded for Black-tailed Godwit, Avocet and Redshank at Ria de Aveiro (see text).

of evidence also point to the relationship between wader declines and roost degradation. Dramatic changes in the estuarine landscape occurred with the abandonment of salt exploitation in the last 40-50 years, which maintained 221 active saltpans by the end of the 1950s (Silva 1958), decreasing to 10 in the 1990s (Brito 1994), and that is presently represented by only one working saltpan. The abandonment or conversion of saltpans into aquacultures frequently compromises their suitability for waterbirds, mostly in consequence of the irregularity or excessive water levels in the tanks (e.g. Masero 2003), and at the Tagus estuary there are several examples of such a negative impact. Even 


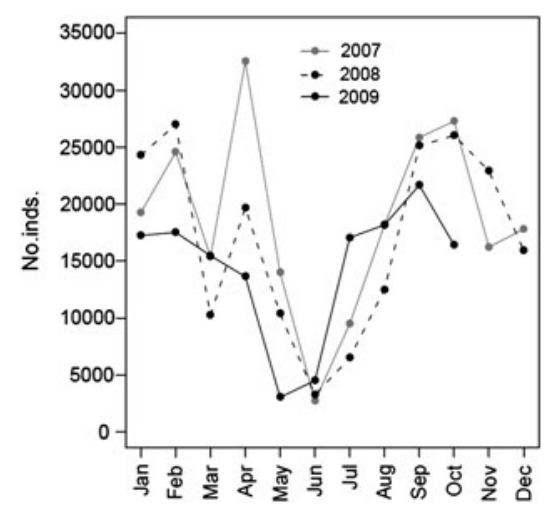

Figure 4. Seasonal abundance of waders in the Tagus estuary in 2007, 2008 and 2009, assessed by roost counts.

roosts located within the SPA boundaries, particularly saltpans, are threatened by transformation into aquacultures (all but two roosts, Vale de Frades and Samouco, face this situation). Vasa Sacos saltpans (roost 2), traditionally one of the most important roosts in the Tagus estuary, were abandoned and then recently converted into grass shrimp Palaemonetes varians aquaculture. During this process the number of birds decreased dramatically. Recent management actions, such as the control of water levels in the tanks, resulted in an increase in the number of roosting waders, but those are still far below the numbers recorded prior to the onset of the commercial exploitation. For instance, average numbers of Dunlin between January and March reached 5,000 birds before shrimp exploitation (when the saltpans were abandoned but water levels were managed for birds; Lecoq 2002) and barely exceeded 2,000 birds in the same period in 2009. A similar situation was recorded at Vale de Frades saltpans that harboured approximately 1,500 wintering Dunlins when water levels were regularly controlled (Lecoq 2002) and had an average of 230 Dunlins in the absence of any management measure during the winters of 2007-2009. Another roost, Alverca (roost I), an isolated saltpan complex on the north of the estuary has suffered severe continuous habitat degradation (with dykes and gates that allow water control destroyed and uncontrolled growth of invasive vegetation following saltpan abandonment) and was partly converted into a sewage treatment station. Despite

Table 4. Seasonal importance (\% of birds) of the monitored roosts for waders at the Tagus estuary (20072009).

\begin{tabular}{lcccc}
\hline & Winter & Spring & Summer & Autumn \\
\hline Alhos Vedros & 16.2 & 6.3 & 8.1 & 8.1 \\
Alverca & 0.2 & 0.6 & 0.2 & 0.0 \\
Atalaia & 0.3 & 1.2 & 1.1 & 0.4 \\
Bela Vista & 0.1 & 0.1 & 0.3 & 0.1 \\
Corroios & 8.3 & 2.9 & 7.3 & 6.1 \\
Moita & 0.8 & 0.0 & 0.0 & 0.0 \\
Samouco & 39.3 & 73.9 & 47.6 & 58.2 \\
Sarilhos & 7.0 & 2.8 & 2.7 & 2.5 \\
Seixal & 5.4 & 0.5 & 0.9 & 2.0 \\
Tarouca & 0.3 & 1.6 & 3.2 & 0.1 \\
Vale de Frades & 5.1 & 7.2 & 25.5 & 11.4 \\
Vasa Sacos & 17.1 & 0.8 & 1.5 & 9.0 \\
Coina & - & 15,826 & 12,552 & 2.1 \\
Number of birds & 22,703 & & 25,543 \\
\hline
\end{tabular}


Table 5. Proportion of waders using roosts outside the Special Protection Area for Birds (SPA). Total numbers of birds in each season are presented in brackets.

\begin{tabular}{lcccccc}
\hline & All waders & Dunlin & Grey Plover & Bt Godwit & Avocet & Redshank \\
\hline Winter & $30.8(22,703)$ & $31.0(11,022)$ & $31.2(2,771)$ & $30.3(2,691)$ & $37.5(1,532)$ & $35.1(1,060)$ \\
Spring & $12.2(15,826)$ & $9.5(10,381)$ & $26.5(1,750)$ & $14.5(361)$ & $3.0(145)$ & $30.5(160)$ \\
Summer & $16.6(12,552)$ & $3.5(4,205)$ & $0.1(1,057)$ & $28.2(2,535)$ & $0(173)$ & $51.2(1,281)$ \\
Autumn & $16.2(25,543)$ & $6.2(7,707)$ & $12.4(3,932)$ & $26.6(5,022)$ & $34.4(126)$ & $38.1(1,724)$ \\
\hline
\end{tabular}

its strategic location, and of being classified as an Important Bird Area for harbouring important numbers of wintering Avocets (BirdLife International 2009), this roost presently has virtually no waders.

Different factors are potentially threatening other roosts. Some roosting sites in the southern part of the estuary (Corroios, Seixal, Alhos Vedros) that sustain large numbers of waders are in close proximity to major urban centres, and yet lack formal legal protection. The proximity to urban centres implies episodic disturbance due to human presence (e.g. shellfishers, leisure activities) degrading the stable and quiet conditions required by waders for roosting.

The loss of high tide roosts may render important intertidal areas inaccessible to birds, and thus high quality areas may become too far away to be profitability exploited (Dias et al. 2006; van Gils et al. 2006). In fact, previous studies have shown that the location of high tide roosts influences the use of tidal flats by Dunlins in the Tagus estuary (Dias et al. 2006), as birds need to minimise flight costs and predation risk in routine movements (Rehfisch et al. 1996, Rogers et al. 2006). Dias et al. (2006) showed that fewer than $20 \%$ of Dunlins forage more than $5 \mathrm{~km}$ away from their roosts, and concluded that the lack of roosts might explain the underuse of north-west intertidal areas of the Tagus estuary.

\section{Variability in roost use requires a network of high quality roosting sites}

Roost fidelity and roost preferences are thought to be variable among waders (Rehfisch et al. 2003, Conklin et al. 2008). In the Tagus estuary, the suitability of roosts for waders is likely to vary with time, as indicated by changes in the relative importance of individual roosts across seasons. Accordingly, previous studies have shown large variations in patterns of roost-use by waders, somehow unrelated to roost quality. In California, less-used roosts by Dunlins were not the ones with lower quality (assessed as a measure of distance to foraging areas and predation risk) nor were used only when preferred roosts were unavailable, suggesting that roost site selection is a rather complex and state-dependent process (Conklin et al. 2008). This reinforces the idea that it is crucial to maintain a network of high quality roosts within the same wetland to ensure the conservation of a large and diverse wader community. Nonetheless, the loss of a particular roost can have severe negative consequences for species showing strong roost fidelity (Rehfisch et al. 2003) or for the whole wader community during specific periods of their life-cycle. During the spring migration, c. $80 \%$ of all the waders in the Tagus estuary concentrate at the Samouco saltpans. This highlights the importance of the Samouco roost in the Tagus estuary and the vulnerability of migrant waders to the loss of one particular roost.

The maintenance of a network of high quality roosts at the Tagus estuary depends on the implementation of a wide range of management measures. At saltpans, the control of water level, the maintenance of exposed margins and the control of invasive vegetation in the tanks and tank walls of saltpans has been shown to be particularly important (Dias 2009). At the southern estuary, most high tide roosts located in saltmarshes are threatened by the expansion of urban areas and crescent human disturbance. The classification of these sites as a Special Protection Area would be the first and most important step for their conservation. Artificial roosts have been successfully implemented to mitigate the loss of natural refuges (Furness 1973, Burton et al. 1996) 
and could potentially provide an alternative to actual roosting sites in the Tagus estuary. Strategically located artificial refuges could even increase the carrying capacity of the estuary by allowing waders to exploit tidal areas that are currently too far from any high-tide roost (Dias et al. 2006).

\section{Conclusions}

This study (I) provides evidence of declining trends for some of the most abundant wader species in the Tagus estuary (some of them showing stable or increasing trends in other large estuaries in Portugal), (2) highlights the role of this wetland as a stopover area for waders using the East Atlantic Flyway, (3) presents evidence of seasonal variation in roost use by waders, emphasising the need for a network of good quality roost sites, which are at present highly threatened by human activities and (4) identifies the degradation of roost quality as a likely cause for wader declines. The established monitoring programme will be crucial to update the persistence of population trends. Concurrently, roost quality parameters should be established, involving quantitative indicators, and their evolution should also be monitored. In this process, all efforts should be conducted to identify the specific threats that wader populations are facing (particularly during the migratory period), and to provide evidence-based data for a concerted conservation strategy.

\section{Supplementary Material}

The online supplementary materials for this article can be found at journals.cambridge.org/bci

\section{Acknowledgements}

We are particularly grateful to all the volunteers that helped with roost counts since 2007, namely Catarina Miranda, João Jara and Mafalda Figueiredo. We would also like to acknowledge all the land-owners/renters who gave us permission to access private wader roosting sites in the Tagus estuary, in particularly to Sr. Eduardo Guedes, Sr. Almiro Sousa, Sr. José Almeida, Fundação das Salinas do Samouco, and also to the Natural Reserve of the Tagus Estuary (RNET). Rafael Matias kindly provided some of his drawings (Dunlin, Grey Plover and Avocet) to be included in Appendix Si. We thank two referees for valuable comments on the manuscript. Since October 2008, this study has been partly supported by Fundação para a Ciência e Tecnologia (FCT) through the Project "MigraTagis" (PTDC/MAR/66319/2006). TC and MPD beneficiated of postdoctoral grants from FCT (SFRH/BPD/46967/2008 and 46827/2008, respectively).

\section{References}

Alves, J. A. (2009) Implications of migration strategies and winter location in a migratory shorebird. Unpublished $\mathrm{PhD}$ thesis, University of East Anglia, Norwich, UK.

Atkinson, P. W., Austin, G. E., Rehfisch, M. M., Baker, H., Cranswick, P., Kershaw, M., Robinson, J., Langston, R.H.W., Stroud, D. A., Van Turnhout, C. and Maclean, I.M.D. (2006) Identifying declines in waterbirds: The effects of missing data, population variability and count period on the interpretation of longterm survey data. Biol. Conserv. 130: 549-559.
BirdLife International (2009) Important Bird Area Factsheet: Salinas de Alverca e Forte Casa, Portugal. Downlowded from Data Zone at http://www.birdlife.org.

Brito, B. G. P (1994) A Aquacultura no Estuário do Tejo: caracterização preliminar. Seminário sobre Recursos Haliêuticos, Ambiente, Aquacultura e Qualidade do Pescado da Península de Setúbal. Setúbal, Portugal: IPIMAR.

Burton, N. H. K., Evans, P. R. and Robinson, M. A. (1996) Effect on shorebird numbers of disturbance, the loss of a roost site and its replacement by an artificial island at 
Hartlepool, Cleveland. Biol. Conserv. 77: 193-201.

Conklin, J. R., Colwell, M. A. and FoxFernandez, N. W. (2008) High variation in roost use by Dunlin wintering in California: implications for habitat limitation. Bird Conserv. Int. 18: 275-291.

Costa, L. T. and Rufino, R. (1994) Contagens de aves aquáticas em Portugal. Janeiro de 1994. Airo 5: 8-16.

Costa, L. T. and Rufino, R. (1997) Contagens de aves aquáticas em Portugal. Janeiro de 1997. Airo 8: 25-32.

Davidson, N. C. and Rothwell, P. I. (1993) Disturbance to waterfowl on estuaries. Wader Study Group Bull. Special Issue 68: $3-5$.

Delany, S., Scott, D., Dodman, T. and Stroud, D., eds. (2009) An atlas of wader populations in Africa and western Eurasia. Wageningen, The Netherlands: Wetlands International and International Wader Study Group.

Dias, M. P. (2009) Use of salt ponds by wintering shorebirds throughout the tidal cycle. Waterbirds 32: 531-537.

Dias, M. P., Granadeiro, J. P., Lecoq, M., Santos, C. D. and Palmeirim, J. M. (2006) Distance to high-tide roosts constrains the use of foraging areas by dunlins: implications for the management of estuarine areas. Biol. Conserv. 131: 446-452.

Dias, M. P., Peste, F., Granadeiro, J. P. and Palmeirim, J. M. (2008) Does traditional shellfishing affect foraging by waders? The case of the Tagus estuary (Portugal). Acta Oecol. 33: 188-196.

Durell, S. E. A. le V. dit, Stillman, R. A., Triplet, P., Aulert, C., Biot, D. O. dit, Bouchet, A., Duhamel, S., and GossCustard, J. D. (2005) Modelling the efficacy of proposed mitigation areas for shorebirds: a case study on the Seine Estuary, France. Biol. Conserv. 123: 67-77.

Durell, S. E. A. le V. dit, Stillman, R., Caldow, R. W. G., McGrorty, S., West, A. D. and Humphreys, J. (2006) Modelling the effect of environmental change on shorebirds: a case study on Poole Harbour, UK. Biol. Conserv. 131: 459-473.

Frederiksen, M., Fox, A. D., Madsen, J. and Colhoun, K. (2001) Estimating the total number of birds using a staging site. $J$. Wildl. Manage. 62: 282-289.

Furness, R. W. (1973) Roost selection in waders. Scott. Birds 7: 281-287.

Galbraith, H., Jones, R., Park, R., Clough, J., Herrod-Julius, S., Harrington, B. and Page, G. (2005) Global climate change and sea level rise: potential losses of intertidal habitat for shorebirds. Washington DC: USDA Forest Service General Technical Report. Pp. 1119-1122.

Gillings, S., Atkinson, P. W., Baker, A. J., Bennett, K. A., Clark, N. A., Cole, K. B., González, P., Kalasz, K. S., Minton, C. D. T., Niles, L. J., Porter, R. C., Serrano, I. L., Sitters, H. P. and Woods, J. L. (2009) Staging behaviour in Red Knot (Calidris canutus) in Delaware Bay: implications for monitoring mass and population size. The Auk 126: 54-63.

Goss-Custard, J. D. and Yates, M. G. (1992) Towards predicting the effect of salt-marsh reclamation on feeding bird numbers on the Wash. J. Appl. Ecol. 29: 330-340.

Hammer, Ø., Harper, D. A. T. and Ryan, P. D. (200I) PAST: Paleontological Statistics Software Package for Education and Data Analysis. Paleontologia Electronica 4: 1-9.

International Wader Study Group (2003) Waders are declining worldwide. Conclusions from the 2003 International Wader Study Group Conference, Cádiz, Spain. Wader Study Group Bull. 101/102: 8-12.

Lecoq, M. (2002) Influência da Localização do Refúgio de Preia-mar na Selecção das Áreas de Alimentação Entre-marés pelo Pilrito-comum Calidris alpina. Umpublished First Degree Thesis, Faculdade de Ciências da Universidade de Lisboa, Portugal.

Lopes, R. J., Múrias, T., Cabral, J. A. and Marques, J. C. (2005) A ten year study of variation, trends and seasonality of a shorebird community in the Mondego estuary, Portugal. Waterbirds 28: 8-18.

Lourenço, P. M., Kentie, R., Schroeder, S., Alves, J. A., Groen, N., Hooijmeijer, J. C. E. W. and Piersma, T. (2010) Phenology, stopover dynamics and population size of migrating Black-tailed Godwits Limosa limosa limosa at a key staging area, the Tejo and Sado rice plantations. Ardea 98: 35-42. 
Masero, J. A. (2003) Assessing alternative anthropogenic habitats for conserving waterbirds: salinas as buffers against the impact of natural habitat loss for shorebirds. Biodivers. Conserv. 12: 1157-1173.

Masero, J. A., Pérez-Hurtado, A., Castro, M. and Arroyo, G. M. (2000) Complementary use of intertidal mudflats and adjacent salinas by foraging waders. Ardea 88: 177-191.

Masero, J. A., Santiago-Quesada, F., SánchezGusmán, J. M., Villegas, A., AbadGómez, J. M., Lopes, R. J., Encarnação, V., Corbacho, C. and Morán, R. (2011) Long lengths of stay, large numbers, and trends of the Black-tailed Godwit Limosa limosa in rice fields during spring migration. Bird Conserv. Internat 21: 12-24.

Mitchell, J. R., Moser, M. E. and Kirby, J. S. (1988) Declines in midwinter counts of waders roosting on the Dee estuary. Bird Study 35: 19 l-198.

Moreira, F. (1995) A utilização das zonas entre-marés do Estuário do Tejo por aves aquáticas e suas implicações para os fluxos de energia na teia trófica estuarina. $\mathrm{PhD}$ Thesis. University of Lisbon, Lisbon.

Moreira, F. (1997) The importance of shorebirds to energy fluxes in a food web of a south European estuary. Estuar. Coast. Shelf Sci. 44: 67-78.

Pannekoek, J. and van Strien, A.. (2001) TRIM (Trends and Indices for Monitoring Data). Vooburg: Centraal Bureau voor de Statistiek (CBS). (Research paper no. 1020).

Peters, K. A. and Otis, D. L. (2007) Shorebird roost-site selection at two temporal scales: is human disturbance a factor? J. Appl. Ecol. 44: 196-209.

Pfister, C., Harrington, B. A and Lavine, M. (1992) The impact of human disturbance on shorebirds at a migration staging area. Biol. Conserv. 60: 115-26.

R Development Core Team (2007) R: A language and environment for statistical computing. Vienna: R Foundation for Statistical Computing. http://www.R-project.org.

Rehfisch, M. M., Clark, N. A., Langston, R. H. W. and Greenwood, J. J. D. (1996) A guide to the provision of refuges for waders: an analysis of 30 years of ringing data from the Wash, England. J. Appl. Ecol. 33: 673-687.
Rehfisch, M. M., Insley, H. and Swann, B. (2003) Fidelity of overwintering shorebirds to roosts on the Moray Basin, Scotland: implications for predicting impacts of habitat loss. Ardea 91: 53-70.

Rehfisch, M. M., Austin, G. E., Freeman, S. N., Armitage, M. J. S. and Burton, N. H. K. (2004) The possible impact of climate change on the future distributions and numbers of waders on Britain's non-estuarine coast. Ibis 146: 70-81.

Rogers, D. I. (2003) High-tide roost choice by coastal waders. Wader Study Group Bull. 100: 73-79.

Rogers, D. I., Piersma, T. and Hassel, C. J. (2006) Roost availability may constrain shorebird distribution: exploring the energetic costs of roosting and disturbance around a tropical bay. Biol. Conserv. 133: 225-235.

Rosa, S., Encarnação, A. L., Granadeiro, J. P. and Palmeirim, J. M. (2006) High-tide roost selection by waders: maximizing feeding opportunities or avoiding predation? Ibis 148: 88-97.

Rufino, R. (1979) Limícolas em Portugal. Lisboa, Portugal: Secretaria de Estado do Ambiente, CEMPA.

Rufino, R. (1982) Contagens de aves aquáticas. Janeiro 1982. Lisboa, Portugal: CEMPA, SNPRCN

Schaub, M., Pradel, R., Jenni, L. and Lebreton, J. D. (2001) Migrating animals stop over longer than usually thought: an improved capture-recapture analysis. Ecology 82: 852859.

Silva, J. F. (1958) Inquérito à Indústria do Sal. Salgado do Tejo, VII Volume. Lisboa, Portugal: Editor Comissão Reguladora dos Perodutos Químicos e Farmacêuticos.

Soldaat, L., Visser, H., van Roomen, M. and van Strien, A. (2007) Smoothing and trend detection in waterbird monitoring data using structural time-series analysis and the

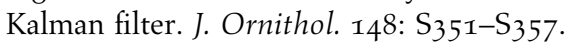
van de Kam, J., Ens, B., Piersma, T. and Zwarts, L. (2004) Shorebirds: an illustrated behavioural ecology. Utrecht, The Netherlands: KNNV Publishers.

van Gils, J. A., Spaans, B., Dekinga, A. and Piersma, T. (2006) Foraging in a tidally structured environment by red knots 
(Calidris canutus): ideal, but not free. Ecology 87: 1189-1202.

Visser, H. (2004) Estimation and detection of flexible trends. Atmos. Environ. 38: 41354145 .
Watkinson, A. R., Gill, J. A. and Hulme, M. (2004) Flying in the face of climate change: a review of climate change, past, present and future. Ibis 146 S1: 4-10.

\section{TERESA CATRY*, JOSÉ P. GRANADEIRO, CARLOS D. SANTOS}

Centro de Estudos do Ambiente e do Mar (CESAM)/Museu Nacional de História Natural, Universidade de Lisboa, Rua da Escola Politécnica 58, 1250-102 Lisboa, Portugal.

JOSÉ A. ALVES

Centre for Ecology Evolution and Conservation, School of Biological Sciences, University of East Anglia, Norwich, NR4 ${ }_{7}$ TJ, UK.

\section{JOANA ANDRADE}

Sociedade Portuguesa para o Estudo das Aves, Av. da Liberdade $n^{\circ} 1052^{\circ}$ esq, 1250-14o Lisboa, Portugal.

\section{HELDER COSTA}

Av. Eng. Arantes e Oliveira, 23-9 A, 1900 Lisboa, Portugal.

MARIA P. DIAS

Unidade de Investigação em Eco-Etologia, ISPA. R. Jardim do Tabaco, 34. 1149-o41 Lisboa \& Museu Nacional História Natural, Universidade de Lisboa, Rua da Escola Politécnica 58, 1250-102 Lisboa, Portugal.

\section{PEDRO FERNANDES}

Rua da República da Bolivia, 36 1 $^{\circ}$ Dto, 150o-548 Lisboa, Portugal.

\section{ANA LEAL}

Centro de Biologia Ambiental, Departamento de Biologia Animal, Faculdade de Ciências, Universidade de Lisboa, 1749-016 Lisboa, Portugal.

PEDRO M. LOURENÇO

Animal Ecology Group, Centre for Ecological and Evolutionary Studies, University of Groningen, P.O. Box 14, 9750AA Haren, The Netherlands.

\section{RICARDO C. MARTINS}

Centro de Biologia Ambiental (CBA)/Museu Nacional História Natural, Universidade de Lisboa, Rua da Escola Politécnica 58, 1250-102 Lisboa, Portugal.

\section{FILIPE MONIZ}

Reserva Natural do Sapal de Castro Marim e Vila Real de Santo António. Sapal de Venta Moinhos, Apartado 7. 8950-999 Castro Marim, Portugal.

\section{SARA PARDAL}

IMAR - Institute of Marine Research, Zoology Department, University of Coimbra, 3004-517 Coimbra, Portugal. 


\section{AFONSO ROCHA}

Rua Luís de Camões $n^{\circ} 52,3^{\circ}$ Esq. 2890-o84 Alcochete, Portugal.

\section{VITOR ENCARNAÇÃO}

Instituto da Conservação da Natureza e Biodiversidade, Rua de Santa Marta 55, 1169-230 Lisboa, Portugal.

*Author for correspondence; e-mail: teresa_catry@yahoo.com

Received 20 May 2010; revision accepted 30 October 2010; Published online 11 February 2011 